\title{
Philanthrocapitalism and crimes of the powerful
}

\author{
Linsey McGoey, Darren Thiel, Robin West
}

This article has two main aims. First, we define and describe the notion of 'philanthrocapitalism,' a global movement that purports to make philanthropy more effective by applying the market logic of the corporate sector to the charitable sector. In contrast to other analyses of philanthrocapitalism, we suggest that an increase in the scale of private disbursements is not the defining feature of new philanthropic models. What is new is the use of bequests from philanthropic organizations such as the Bill and Melinda Gates Foundation to directly subsidize large corporations. This point leads to our second main aim, which is to argue that the most important feature of the new philanthropy is the way that pro-market rhetoric espoused by philanthrocapitalists helps to confer moral legitimacy on pro-corporate government regulation and public spending that directly exacerbates economic inequality. Importantly, this moral legitimacy can only last as long as the negative effects of pro-corporate government wealth transfers on the public purse are strategically ignored. We suggest that philanthrocapitalist organizations perform an epistemological and moralizing function which renders corporate harms less apparent to the public. Drawing on Max Weber's concept of charismatic authority and on research by criminologists into social harms and crimes of the powerful, we explore how and why elite philanthropic actors, whose existence and actions often harm the public, have managed to successfully uphold the push for market solutions to human problems as socially beneficial.

Keywords: philanthrocapitalism, marketisation, public-private partnerships, charisma, social harm, strategic ignorance.

Linsey McGoey is a Reader in Sociology at the University of Essex. She is author of No Such Thing as a Free Gift (Verso, 2015) and The Unknowers (Zed, 2018). She is a founding editor of the Routledge Research in Ignorance Studies book series, and an editorial board member at the journal Economy and Society. With colleagues at Essex, she is part of the Human Rights and Big Data Technology project, funded by the ESRC.

Darren Thiel is a Senior Lecturer in Sociology at the University of Essex, UK. He has published a number of works about the UK construction industry, social policy and criminal justice policy, including his book Builders (Routledge, 2012), and his co-authored Criminology: A Sociological Introduction (Routledge, 2014). He recently carried out an interviewed-based project on UK welfare reform, and is increasingly interested in studying the powerful.

Robin West is a Lecturer in the Department of Sociology, University of Essex, UK, where he teaches criminology and social theory. His current research interests range from an exploration of the social and environmental effects of corporate mining initiatives in Northern Italy to the memorialization and representation of atrocity in Korea. 


\section{Introduction: Vampires, zombies and lovers}

Critics of capitalism often use horror metaphors to symbolise the predatory nature of capitalist profiteering. Marx famously suggested that capital thrives 'vampire-like' from 'sucking living labour, and lives the more, the more labour it sucks.' ${ }^{1}$ More recently, the American journalist Matt Taibbi invoked Marx's metaphor when describing the investment firm Goldman Sachs as a 'great vampire squid...relentlessly jamming its blood funnel into anything that smells like money." While such metaphors effectively illuminate the violent effects of wealth expropriation, they are less effective when it comes to explaining capitalism's smiling face and the broad range of ways in which a new generation of entrepreneurs and philanthropists have managed to authoritatively claim that growing private wealth concentration is naturally munificent for all humanity.

Understanding the power of today's wealth elites requires metaphors not simply of predation - but of love and adoration. The contemporary philanthrocapitalist is neither a vampire nor a 'zombie economist', ${ }^{3}$ but rather a benevolently smiling figure whose appeal is rooted in the power of a 'harmony ideology' that claims to reconcile the act of taking with the act of giving. ${ }^{4}$ Like a lover and not a villain, today's philanthrocapitalist arrives bearing flowers, claiming that it is possible to both do good things socially and do well financially.

This article explores the social implications of new philanthropic movements which claim to improve public welfare by encouraging businesses to be more socially responsible. ${ }^{5}$ The data is drawn partly from McGoey's qualitative study of large philanthropic foundations, which was centred on a textual analysis of 990 IRS reporting forms from large organizations like the Gates Foundation, as well as 55 qualitative interviews with stakeholders at the World Health Organization, the Gates Foundation, and other charitable organizations. ${ }^{6}$ In this present article, we add new insights by also drawing on publicly available data and analysing the social and economic implications of novel and pro-corporate shifts in the philanthropic sector,

\footnotetext{
${ }^{1}$ Marx, K. 1977. Capital. Vol 1. Vintage Books, New York, p. 342.

${ }^{2}$ Taibbi, M. 2010. "The Great American Bubble Machine.” Rolling Stone. April 10.

${ }^{3}$ Quiggin, J. 2010. Zombie Economics: How Dead Ideas Still Walk Among Us. Princeton University Press, New Jersey.

${ }^{4}$ The term 'harmony ideology' was coined by the anthropologist Laura Nader. See Nader, L. 1994. 'Coercive Harmony: the Political Economy of Legal Models' Kroeber Anthropological Society Papers Vol 80: 1-13; see also Illouz, E. 2007. Cold Intimacies: The Making of Emotional Capitalism, Polity Press, Cambridge and Konings, M. 2015. The Emotional Logic of Capitalism. Stanford University Press.

${ }^{5}$ See Barman, E. 2106. Caring Capitalism: The Meaning and Measure of Social Value. Cambridge University Press.

${ }^{6}$ McGoey, L. 2015. No Such Thing as a Free Gift. Verso, London.
} 
drawing links between philanthrocapitalism, 'crimes of the powerful' and the 'social harms' perspective. ${ }^{7}$

In the first section, we introduce and define the philanthrocapitalism movement. The 'new' philanthrocapitalists often claim that the scale of philanthropic giving today is what makes today's philanthropy different to the past. However, while some analyses suggest that global philanthropy is increasing, giving levels in many wealthy nations are not rising. In the US, for example, charitable giving has stayed stagnant for nearly 50 years, at approximately two percent of overall GDP. What really is new about the new philanthropy is not the magnitude of its giving, but the structure of its gifts - and, in this respect, there have been two main developments.

The first, spearheaded by the Gates Foundation, is a new trend to direct tax-privileged 'philanthropic' grants to corporate recipients. The second is the decision by other wealthy billionaires to establish for-profit limited liability companies to disburse their philanthropy. These trends are helping to concretise and expand earlier, longer-standing, operational changes in public services delivery - changes that have commonly not been positive ones for vulnerable populations. ${ }^{8}$

We suggest that the growing reliance on private, for-profit actors to deliver charity and public services is legitimated partly as a result of the popularity of celebrity mega-rich philanthrocapitalists such as Bill Gates, Mark Zuckerberg, and Pierre Omidyar, who have aggressively advocated an ideology of 'market munificence' - the belief that marrying corporate profits with social welfare can lead to general prosperity. Yet, as we show, the idea that private enterprise is 'naturally' beneficial for humanity is not a new idea, but rather has its roots in the ideas of $18^{\text {th }}$ century scholars such as the influential economist Adam Smith. Importantly, however, Smith's actual writing advocated for government regulation to ensure that commerce and trade activity did not harm the public. This aspect of Smith's writing is

\footnotetext{
${ }^{7}$ See, for example, Carrabine, E, Cox, P, Fussey, P, Hobbs, D, South, N, Thiel, D and Turton, J. 2014. Criminology: A Sociological Introduction. Routledge, New York, p. 474 ; Brisman, A. and South, N. 2015. 'State-Corporate Environmental Harms and Paradoxical Interventions: Thoughts in Honour of Stanley Cohen' in R. A. Sollund (ed.), Green Harms and Crimes. Springer.

${ }^{8}$ Dowling, E. 2016.: 'In the Wake of Austerity: Social Impact Bonds and The Financialisation of the Welfare State,' New Political Economy, doi/full/10.1080/13563467.2017.1232709; Bowman, A. 2015. What a Waste: Outsourcing and How it Goes Wrong. University of Manchester Press; Pensiero, N. 2017. 'In-house or outsourced public services? A social and economic analysis of the impact of spending policy on the private wage share in OECD countries' International Journal of Comparative Sociology. 58(4) 333-351.
} 
ignored by today's philanthrocapitalists, who only selectively draw on favourable aspects of it to defend their increased wealth concentration.

Through an analysis of changes in attitudes to corporate social responsibility from figures like Smith through to late- $20^{\text {th }}$ century figures such as Milton Friedman, we argue that growing cultural reverence for today's philanthrocapitalism has helped to make the public more trusting in 'doux commerce" ${ }^{9}$ narratives of capitalist growth. In line with this, we show how the power and charismatic appeal of the philanthrocapitalists is rooted in and bolstered by a pervasive strategic ignorance of the long-standing interconnectedness of the state and the market, a form of social blindness that enables figures such as Gates to powerfully suggest that introducing for-profit strategies to the charitable realm will 'naturally' produce social advantages.

The authority of influential super-rich figures like Bill Gates performs a mystifying function, compounding unawareness of the social costs and harms of corporate wealth accumulation and the private delivery of charity and public services. Spurious and yet largely unchallenged claims from popular figureheads about the 'revolutionary' effects of market incentives are treated as a proxy for the truth, facilitating the public perception that new partnerships between the public and private sectors are as effective as their champions imply. ${ }^{10}$ Our analysis of the philanthrocapitalism movement thus demonstrates the ways that corporate power is not only capturing the traditional ground of the state, but is equally capturing its ethical ground, and, in the process, legitimising an enhanced, anti-democratic role for the super-rich and their self-serving philosophies to determine the operational models and appropriate levels of welfare for the less advantaged.

\section{Philanthrocapitalism: what is new and what isn't?}

The term 'philanthrocapitalism' was coined in 2006 by an editor at The Economist magazine, Matthew Bishop, ${ }^{11}$ which he later expanded on in a co-authored book: Philanthrocapitalism: How The Rich Can Save the World. Philanthrocapitalism is defined in two chief ways. First, it is hailed as 'a new way of doing philanthropy, which mirrors the way that business is done in the for-profit capitalist world.' Secondly, it advances the idea that 'capitalism itself can be

\footnotetext{
${ }^{9}$ Hirschman A. 1982. 'Rival Interpretations of Market Society: Civilizing, Destructive, or Feeble?' Journal of Economic Literature XX:1463-84.

${ }^{10}$ Bowman, A. 2015.

11 Bishop, M. 2006."The Birth of Philanthrocapitalism: The Leading New Philanthropists See Themselves as Social Investors", The Economist, February 23.
} 
philanthropic, working for the good of mankind.' Its adherents see capitalist enterprise as a 'naturally' altruistic mode of production and they argue that there is a normative case for directing government subsidies and private philanthropic resources directly to corporate recipients. $^{12}$

A key claim of the new philanthrocapitalism is that business is good for charity. By seeking to apply methods and the tactics from the corporate sector to the realm of philanthropy, philanthrocapitalists aim to "find ways of harnessing the profit motive to achieve social good'13. Advocates also believe the flipside: they argue that if corporations embrace corporate social responsibility initiatives, they can 'do good by doing well,' enabling various corporate sectors to improve social welfare while increasing profits. ${ }^{14}$

Now over ten years old, philanthrocapitalism has begun to attract growing attention from social scientists, ${ }^{15}$ but precisely how the new movement differs from earlier approaches to philanthropic giving is not always clear. For example, recent high-profile acts of megagiving have made it seem as if the generosity and scale of giving from individual benefactors is unprecedented in scale. In 2006, for instance, Warren Buffett, one of the world's wealthiest investors, made a bequest of $\$ 30$ billion to the Bill and Melinda Gates Foundation, and, in 2015, Facebook's Mark Zuckerberg announced that he planned to gift $\$ 40$ billion - most of his fortune - to charity, eliciting widespread praise from the media and public.

When it comes to sheer dollar amounts, mega-gifts from today's super-rich do seem unprecedented and - for most of the world's public - almost incomprehensively large sums of money. Joel Fleishman, who has written about the history of philanthropic foundations, points out that Buffett's gift of $\$ 30$ billion represented in 2006 dollars more than the $19^{\text {th }}$ century philanthropists, John. D. Rockefeller and Andrew Carnegie, gave away over their lifetimes combined. ${ }^{16}$ However, proportionately, as a percentage of the American economy these gifts

\footnotetext{
${ }^{12}$ Quoted excerpts are available at http://philanthrocapitalism.net/about/faq/

13 Bishop, M and Green, M, 2008. Philanthrocapitalism: How the Rich Can Save the World. Bloomsbury, London. p. 6.

${ }^{14}$ C.f. Porter, M. and Kramer, M. 1999. 'Philanthropy's New Agenda: Creating Value'. Harvard Business Review (November/December); Porter, M. and Kramer, M. 2002. 'The Competitive Advantage of Corporate Philanthropy'. Harvard Business Review (December).

${ }^{15}$ See Kohl-Arenas, E. 2016. The Self-Help Myth. University of California Press; Kuldova, T. 2017. 'When Elites and Outlaws do Philanthropy: on the limits of private vices for public benefit' Trends in Organized Crime https://doi.org/10.1007/s12117-017-9323-6; Kish, Z. \& Justin, L. 2015. 'Bonded Life: Technologies of racial finance from slave insurance to philanthrocapital' Cultural Studies, 29: 630-651, DOI: 10.1080/09502386.2015.1017137

${ }^{16}$ Fleishman, J. 2007. The Foundation: A Great American Secret, How Private Wealth is Changing the World, New York, Public Affairs.
} 
actually represent a smaller sum than the bequests made by figures such as Carnegie and Rockefeller.

The perception that a new strata of super-rich individuals signals a new 'golden' era of philanthropic giving is simply not true. Not only has philanthropic giving stayed flat in the US since the 1970s but, proportionately, only a small amount of overall giving there comes from grants made by the super-rich. As David Callahan (2017) observes, gifts donated by wealthy donors in the US represent only a quarter of all charitable giving in that country. This has been affirmed by PhilanthropyRoundtable, an organization tracking charitable investment, when they state: 'individual donations and bequests in wills, [and] personal gifts come to over four times as much, every year, as what behemoths like the Gates, Ford, Walton, etc. foundations plus corporations give away. ${ }^{17}$

It is also the case that giving by philanthropic trusts is minuscule compared to what wealthy nations spend on development aid, as well as what developing countries, from their own revenues, spend on their healthcare and development. Take the example of the Gates Foundation's spending on global health. Here the Foundation outpaces any other private philanthropic foundation in the world, donating between $\$ 1$ and 2 billion to global health each year. While that figure is significant, it is far less than the total overseas aid given by OECD governments which stands at about $\$ 130$ billion annually. Moreover, contrary to much public perception in western nations, most of the revenue that developing countries spend on health comes from their own domestic revenues and not from development aid gifted by other states or private donors like the Gates Foundation. A study from the US-based Institute for Health Metrics and Evaluation has made this clear, reporting recently that: 'In most developing regions, government health spending that is financed by countries' own revenue is much larger than DAH [Development Assistance for Health]. ${ }^{18}$

\section{The 'Bill Chill' Effect}

Despite the fact that the amount spent by wealthy countries on domestic welfare provision and overseas development aid dwarfs the amount spent by private philanthropic foundations, such foundations have become incredibly socially and politically influential - outstripping their actual financial influence. The high visibility of the Gates Foundation, for example, enables it

\footnotetext{
${ }^{17}$ http://www.philanthropyroundtable.org/almanac/statistics/; see also Callahan, D. 2017. The Givers: Wealth, Power, and Philanthropy in a New Gilded Age. Knopf Doubleday, New York. ${ }^{18} \mathrm{http} / / /$ www.healthdata.org/sites/default/files/files/policy_report/2011/FGH2011/IHME_FGH2011_C hapter3.pdf
} 
to leverage its own resources in order to rally partners to the causes it aims to prioritize. As the global health scholar, Laurie Garrett, recently suggested, in the World Health Organization virtually no major policy decisions take place without being "casually, unofficially vetted by Gates Foundation staff.' 19

Another example can be drawn from the Gates Foundation's power over US education policy where its ability to attach specific conditions to its gifts makes it possible to disproportionately influence where and how federal dollars are spent ${ }^{20}$ - despite its negative impact on US public education policy. In 2016, the LA Times newspaper surveyed the record on Gates Foundation's grants towards US education and reached a sobering conclusion: most of the initiatives championed by the Foundation ended in failure, often wreaking havoc for schools. ${ }^{21}$ A case in point was the effort to link teacher retention and promotion to flawed metrics on teacher evaluation, an emphasis that the Gates Foundation eventually abandoned after the evidence of its programme's costs for schools and teachers grew so overwhelming that it was forced to publicly apologize for so strenuously promoting the policy. ${ }^{22}$ The LA Times article also points to other failures, including a 2009 pledge to offer $\$ 100$ million to schools in a district of Florida that were willing to change evaluation systems in a way that created bonuses for high-performers, while the lowest-performing five per cent of teachers were fired. Halfway through the program, the Foundation changed its mind and withheld funding. As the LA Times writes, 'the schools were left with too big a tab... The program, evaluation system and all, was dumped. ${ }^{, 23}$ Studies by scholars Harman and Ravitch document a raft of other failed Gates Foundation initiatives in both health and education. ${ }^{24}$

Something that particularly stands out about the LA Times article is that it was a rare instance when a leading US newspaper had publicly criticized the Gates Foundation. The vast majority of media attention towards the Foundation is positive rather than critical. ${ }^{25}$ This has led some critics to talk of the 'Bill Chill' effect, where even organizations and individuals that

\footnotetext{
${ }^{19}$ Garrett, L. 2012 "Money or Die: A Watershed Moment for Global Public Health," Foreign Affairs (March 6); see also Youde, J. 2012 "The Rockefeller and Gates Foundations in Global Health Governance" Global Society 27 (2): 139-58.

${ }^{20}$ Ravitch, D. 2010. The Death and Life of the Great American School System Basic Books, New York.

${ }^{21}$ LA Times editorial board, 2016, 'Gates Foundation failures show philanthropists shouldn't be setting America's public school agenda' (LA Times, 01/06).

${ }^{22}$ Levine, M. 2016. 'Gates Foundation Apologizes Once Again for "Learning Organization" Missteps' Nonprofit Quarterly Magazine (May 27).

${ }^{23}$ LA Times, 'Gates Foundation failures'.

${ }^{24}$ Harman, S. 2016. 'The Bill and Melinda Gates Foundation and Legitimacy in Global Health Governance' Global Governance 22(3): 349-368. Ravitch, D. 2010. ibid.

${ }^{25}$ See Harman, S, ibid.
} 
are alarmed by the impact of the Foundation on education, development and health policy tend to self-censor their objections for fear of jeopardizing their own revenue streams.

As another example, in 2009, The Lancet, one of the world's leading medical journals, published a series of articles that also sharply criticized the Gates Foundation. It argued that the Foundation often prioritized health interventions that suited its objectives - but not the needs of the developing regions:

The concern expressed to us by many scientists who have long worked in low-income settings is that important health programmes are being distorted by large grants from the Gates Foundation. For example, a focus on malaria in areas where other diseases cause more human harm creates damaging perverse incentives. ${ }^{26}$

Poignantly, however, the more widespread media response, particularly in the US, has been overwhelmingly negative about such criticism: implying that the Gates Foundation should be treated as beyond rebuke. This has the effect of thwarting public discussion of the effectiveness of recent philanthropic decision-making, even when recent structural shifts raise profound questions about the limits of 'philanthropy'. It also raises questions about whether the word 'philanthropy' should even be used to describe economic practices that directly enrich either the giver personally or another wealthy individual or corporation directly, exacerbating the very economic inequalities that donors purport to ameliorate.

\section{Profitable charity and alms for corporations}

Philanthrocapitalist organisations are increasingly directing their grants towards for-profit ventures. For example, the Gates Foundation has begun to offer an increasing proportion of its grants directly to corporate recipients including Vodafone, Mastercard and Scholastic (one of the world's largest education publishers) in the form of non-repayable grants. In 2014, for instance, the Gates Foundation announced an \$11 million grant for Mastercard to set up a 'lab' for financial inclusion in Nairobi. Both the Gates Foundation and Mastercard rationalized this non-repayable grant in corporate terms - as a way for Mastercard to offset some of its business risks. Mastercard emphasized in a press release that the gift from the Gates Foundation had enabled them to reach 'new markets that may otherwise be commercially unviable.'

The decision to offer grants directly to corporations is distinctive but also related to a separate initiative by two other influential billionaires, Mark Zuckerberg, a founder of

${ }^{26}$ The Lancet, 2009. 'What has the Gates Foundation Done for Global Health? 373(9675): 1577 
Facebook, and Pierre Omidyar, a founder of eBay, who have each established for-profit LLCs to disburse their wealth - instead of more traditional philanthropic foundations. This enables them to avoid government regulations on private philanthropic trusts - even while Omidyar and Zuckerberg claim publicly that their for-profit entities are 'philanthropic. ${ }^{27}$

The tax benefits received by US philanthrocapitalists as a result of these novel gifting processes are complex, and they vary depending on whether the 'giving' entity is a traditional trust or an LLC. The model of LLCs confers considerable tax benefits and, most importantly, important regulatory benefits on investors. In the US, traditional philanthropic trusts must comply with federal laws that prevent philanthropic trusts from 1) directly influencing political decisions; 2) storing money indefinitely without ever disbursing it to philanthropic causes (trusts must adhere to what are called 'minimum payment obligations'), and 3) using grants to directly enrich a donor. These rules are intended to subject philanthropic trusts to democratic oversight and ensure that gifts are not spent in illegal ways.

A 'philanthropic LLC' can legally avoid all of these rules. They face no 'minimum distribution' requirements to give money to charity each year, and no 'self-dealing restrictions' - the term for when a benefactor must avoid gift-giving that directly profits him or herself. Perhaps most importantly, 'the tax filings for the Zuckerberg Chan Initiative will not have to be made public. ${ }^{28}$ LLCs face no obligation to disclose the amount of compensation paid to staff who manage the wealth, nor provide a public list of grants disbursed. Thus although an LLC is perceived as have fewer tax advantages than a philanthropic trust, in reality, an investor such as Zuckerberg can still claim as many deductions as the Gates Foundation for any charitable gifts made to his LLC. The difference is that, unlike the Gates Foundation, the public is not able to know what percentage of the LLC's investments are going to charity causes, and which percentage is geared at financial investments that directly profit Zuckerberg and his wife. As political scientist Sarah Reckhow observes, new LLCs thus represent an anti-democratic shift in the structure of giving that renders external academic investigation practically impossible. Unlike a traditional trust like the Gates Foundation, no external scholar will be able to study the list of grants offered in order to track the failure or success of different giving

\footnotetext{
${ }^{27}$ Singer, S. and Isaac, M. 2015. ' Mark Zuckerberg's Philanthropy Uses L.L.C. for More Control'. New York Times (December 2). See also work by Sarah Reckhow who points out that Zuckerberg's new LLC model makes philanthropic giving more opaque and harder for external stakeholders to investigate.

${ }^{28}$ Carter, E. 2015. 'LLCs as Philanthropic Vehicles' Charitylawyer

(http://charitylawyerblog.com/2015/12/15/llcs-as-philanthropic-vehicles/\#ixzz58U7pRnHZ
} 
programmes. This makes it feasible for people like Zuckerberg or Omidyar to exaggerate the gains or minimize the harms of failed philanthropic ventures with relative impunity. ${ }^{29}$

The Gates Foundation, unlike LLCs, must provide public access to information about all its grants. ${ }^{30}$ As a result, we know that the Gates Foundation has classified its gifts to large for-profit companies such as Mastercard and Scholastic as part of its 'minimum payment' obligations - a term for the legal requirement to disburse at least five percent of the size of its endowment to charitable ends each year. It means that Foundations must audit and track their grants in order to make sure that a for-profit recipient uses the gift for charitable rather than commercial ends. The result is that the Gates Foundation is legally able to claim an approximately 30 percent tax deduction for its gift to Mastercard. ${ }^{31}$

Notably, even though Mastercard is clearly not a charity, the Gates Foundation has legally defended its gifts to Mastercard and other corporations by emphasizing 'expenditure responsibility' rules. As a representative of the Gates Foundation stated in response to a specific query about the Foundation's gifts to Scholastic: 'In the case of Scholastic, we have treated it exactly as we would any grant to a for-profit entity, which is to say that we have followed all of the expenditure responsibility rules. ${ }^{32}$ Yet whether the nature of 'expenditure responsibility' has actually been followed as the Foundation suggests is somewhat debatable. In the case of Mastercard, the company's own press release praised the Gates Foundation for paying its business costs. Moreover, a number of scholars have queried the legal status of philanthropic gifts to corporations, pointing out that even if the Gates Foundation states otherwise, these 'gifts' do appear to contravene the US charity laws enacted to prohibit tax-privileged organizations from using grants for non-charitable ends. ${ }^{33}$

${ }^{29}$ Reckhow, S. 2017 'What happens when scholars can no longer follow the money' Histphil, January 26. https://histphil.org/2017/01/26/philanthropic-data-and-the-rise-of-llcs-or-what-happens-whenscholars-can-no-longer-follow-the-money/

${ }^{30}$ The Gates Foundation engages in a lot of varied partnerships with the private sector but not all of these partnerships confer tax benefits. For example, the Foundation's endowment has equity stakes in a number of for-profit start-up technology companies, and it must pay tax on any income gains from these equity investments. However, its gifts to Mastercard and other large and profitable companies do confer tax benefits.

${ }^{31}$ The Gates Foundation has suggested in the past that it has used some but not all available tax entitlements open to it. In general, as Ray Madoff describes, US donors can claim anywhere from 30 to 50 percent deductions for their giving. Madoff, R. 2013. 'How the Government Gives' New York Times. ( December. 6).

${ }^{32}$ Email from C. Williams, Gates Foundation, to L. McGoey, on Sept. 2, 2015.

${ }^{33}$ McGoey, L. 2015. 'The Philanthropy Hustle.' Jacobin Magazine; Kuldova, T. 2017. 'When Elites and Outlaws do Philanthropy'; Wright, K., Scott, M. and Bunce, M. 2018. 'Foundation-funded Journalism, Philanthrocapitalism and Tainted Donors' Journalism Studies, https://doi.org/10.1080/1461670X.2017.1417053 
Gifts to corporations are raising under-underexplored questions: should Mastercard be indirectly subsidized by US taxpayers, especially at a time when US corporate profitability, alongside economic inequality, is at an all-time high? In this sense, it is curious and sociologically notable that there is lack of scrutiny surrounding the legality and morality of new gifting practices. The absence of criticism is a 'social fact' that requires explanation particularly as the development signifies a stark shift from how philanthropists were perceived by governments and publics in the past. The next section turns to this history in order to explore the shift in public perceptions about private giving.

\section{Mega-giving in history}

Despite claims to the contrary, the ideology that underpins philanthrocapitalism - the notion that, in Bishop and Green's words, 'capitalism itself can be philanthropic, working for the good of mankind' - has a long history that harks back to a core tenet of $18^{\text {th }}$ century political economy. As we have suggested, in many ways, philanthrocapitalism is simply the most recent iteration of a 'doux commerce' theory of capitalist development which proposes that selfinterest and public benefit are naturally interlinked. ${ }^{34}$ Yet, what is novel is the way in which the ideas that underpin philanthrocapitalism have become so influential today when, at an earlier time, similar ideas embedded in theories of economic liberalism were largely scorned and derided by the public in Europe and North America - seen as a form of ideological whitewashing that served to reinforce the unjust power of plutocratic wealth elites. As the political economist Albert Hirschman argues, narratives proclaiming that individual self-gain can and will 'naturally' advance the public welfare were widely criticized for much of the $19^{\text {th }}$ and $20^{\text {th }}$ centuries by both the public and governmental legislators, and this scepticism was heightened whenever fresh news of corporate scandals and abuses of power were showcased in the media. ${ }^{35}$

Influential thinkers on both the political left and the right pointed out that the interests of commercial expansion and the interests of a political polity did not naturally align in an easy or frictionless manner. This point, following the meteoric rise of the robber-baron capitalists, was made forcefully by early $20^{\text {th }}$ century thinkers such as Louis Brandeis, an influential lawyer, and Ida Tarbell, the investigative journalist whose exposé of big business led to

\footnotetext{
${ }^{34}$ See Edwards, M. 2010. Small Change: Why Business Won't Change the World. Demos, New York and London: McGoey, L. 2012. 'Philanthrocapitalism and its critics'. Poetics 40(2): 185-199.

${ }^{35}$ Hirschman, A. 1982. ibid.
} 
sweeping industry reforms of the time. They insisted that governments need to police and to punish extreme private profiteering.

As an example of this, the very period when John D. Rockefeller sought to obtain a federal charter from the US Government to formally establish his philanthropic foundation, his company, Standard Oil, was facing a protracted antitrust lawsuit launched by the Department of Justice - from which it ultimately found Standard Oil guilty of illegal business practices. Wrongdoing at Standard Oil was, like in almost all large corporations, pervasive and recidivist. ${ }^{36}$ It ranged from corporate espionage to fabricating shadow companies in order to disguise the operation of subsidiaries. Indeed, in 1905, the US senator Robert La Follette denounced Rockefeller as the 'greatest criminal of the age'. ${ }^{37}$

The 'great' philanthropist, Andrew Carnegie, also faced widespread mistrust from legislators and the US public, especially when his violent union-busting tactics became widely known to the public. As the historian David Nasaw writes, one of the paradoxes of Carnegie's philanthropy is that he 'became, if anything, more ruthless in pursuit of profits once he had determined that those profits would be distributed during his lifetime. ${ }^{38}$ Nasaw adds that 'In remonstrating that only the millionaire could be trusted to dispense his millions, and that whatever that millionaire thought 'best' was 'best,' Carnegie was promulgating a profoundly antidemocratic gospel, almost feudal in its paternalism. ${ }^{39}$

Legislators in Brandeis' day were wary of the monopolistic power of companies like Rockefeller's Standard Oil, and US workers and their elected representatives were, in some ways, successful in challenging and restraining the philanthropic 'noblesse oblige' of the rich. They won labour and welfare protections that were in place until the late $20^{\text {th }}$ century, when many workers' protections were again eroded. Such critique also led to the development of significant US legislation to restrict philanthropy from generating personal profit. ${ }^{40}$ Today, however, the voices of figures like Tarbell and Brandeis are less influential, and a new neofeudal vision of prosperity has grown more powerful.

In order to understand this intriguing change in public attitudes, below we draw on Max Weber's notion of 'charismatic authority ${ }^{\text {'1 }}$ that we see as wielded by today's

\footnotetext{
${ }^{36}$ Sutherland, E. 1961[1949]. White Collar Crime. Holt, Rinehart and Winston, New York.

${ }^{37}$ Seim, D. 2013. Rockefeller Philanthropy and Modern Social Science. Routledge, London, p. 50.

${ }^{38}$ Nasaw, D. 2006. 'Introduction' in Carnegie, A. The 'Gospel of Wealth' Essays and other writing. Penguin, London.

${ }^{39}$ Ibid, xii.

${ }^{40}$ Arnove R, Pinede N. 2007. Revisting the 'Big Three' Foundations Critical Sociology 33(3):389-435

${ }^{41}$ Weber, M. 2012. The Theory of Social and Economic Organization. The Free Press, Glencoe, Illinois.
} 
philanthrocapitalists, and which contributes to the 'perpetual immunity' from effective criticism of revered figures like Bill Gates, whose wealth concentration is hailed as positive gain for humanity writ large because he is seen as using that wealth to improve the world. This is despite the growing concern that the emergence of 'top heavy' private philanthropy may be exacerbating rather than narrowing wealth disparities, ${ }^{42}$ and the simple fact that extreme individual wealth is inherently inegalitarian.

\section{Charismatic authority and perpetual immunity}

Three main factors make it difficult to effectively criticize philanthrocapitalist foundations and their ensuing market philosophies. First, as we have suggested, there's the 'chilling' effect whereby those who are often the most knowledgeable about the adverse effects of the increased power of the Gates Foundation, often work in the fields where its grants are focused. These individuals compete for slices of a funding pie - and it is thus more strategic to ignore or to silence their concerns than to voice them. ${ }^{43}$

A second reason why it's difficult to effectively criticize the influence of these foundations is that even if there is critique, that very criticism rarely weakens influence and, indeed, has the opposite effect: it justifies the need for more and better projects - for more economically robust market models. ${ }^{44}$ This kind of 'perpetual immunity' from effective criticism is somewhat akin to the religious and spiritual problems of establishing supernatural authenticity: if engaging in rituals toward God does not yield expected outcomes, the parishioners have either failed to understand God's ways or there needs to be more ritual offering - any alternative view would be heresy. In this vein, the answer to failed philanthrocapitalist endeavours is more 'efficient' solutions - whereby the failure of philanthropy is its success. Thus despite the current economic climate, or, because governmental finances are particularly strapped, mega-givers like Gates appear even more indispensable - and therefore any criticism all the more counterproductive. Somewhat ironically, the greater global and domestic inequality grows the more likely the Gates

\footnotetext{
${ }^{42}$ See Collins, C, Flannery, H, and Hoxie, J. 2016. 'Gilded Giving Top-Heavy Philanthropy in an Age of Extreme Inequality'. (Institute for Policy Studies, November), http://www.ips-dc.org/reportgilded-giving; Reich, R. 2006. 'Philanthropy and its uneasy relation to equality'. In W. Damon and S. Verducci (Eds.), Taking philanthropy seriously: Beyond noble intentions to responsible giving (pp.2750). Indiana University Press, Indianapolis.

${ }^{43}$ See Harman, ibid.'

${ }^{44}$ Power M. 1994. The Audit Explosion. White Dove Press, London.
} 
Foundation will be insulated from criticism, even when its presence may be compounding the very economic inequalities which it purports to be ameliorating. ${ }^{45}$

Thirdly, while an individual like Gates is undeniably gifted at computer programming and amassing wealth, his influence doesn't simply rest on how his fortune was made. Indeed, Gates himself was, in the past, vilified for Microsoft's anti-competitive behaviour which was deemed unlawful by the U.S. Department of Justice and the European Commission. His exemplary acts, then, don't necessary stem from having amassed his wealth - but rather in his wilful surrender of some of his fortune.

The religious overtones involved in the process of perpetual immunity are not simply hyperbole but reflect the sacred status of mega-giving. As Weber suggested, even in secular times and situations, religious notions continue to underpin human conduct and morality. ${ }^{46}$ One form of such spiritual authority is the charisma generated by 'saintly' actions that are perceived as somehow other worldly and connected with God. ${ }^{47}$ While philanthropy is not necessarily or usually linked to organized religion, gift-giving is nonetheless upheld as a sign of moral grace, if not superiority - and mega-giving is thus publicly spectacular. The sanctification generated by acts of mega-giving helps to deflect criticism of philanthropic trusts - not simply because of a 'chilling' effect, but because of what we call 'charismatic love. ${ }^{48}$

A key attribute of the charismatic authority generated by mega-giving is the ability of the charismatic individual to capture the imagination and devotion of a group of congregants in way that allows a 'laity' to associate the figure with what they themselves most cherish about life itself - whereby the bearer of charismatic authority comes to imbue and to impersonate the sacred sphere. ${ }^{49}$ Consequently, even though today an increasing proportion of philanthropic foundation giving is channelled to for-profit actors - because these acts are still called philanthropy, they are perceived by the public as acts of charity - and due to the almost

\footnotetext{
${ }^{45}$ A section of this and the preceding paragraph draw on McGoey, 2012, 'Philanthrocapitalism and its critics.' Poetics.

${ }^{46}$ Weber, M. 2001. The Protestant ethic and the spirit of capitalism. New York, NY and London: Routledge Classics; Weber, M. 2012. The Theory of Social and Economic Organization. The Free Press, Glencoe, Illinois.

${ }^{47}$ C.f. Weber, M. 1993 The Sociology of Religion. Beacon Press, Boston. Weber explicitly suggests that the charismatic figure is someone whose actions are associated with sacred acts and / or the sacred realm. In his words, "charismatic authority is thus specifically outside the realm of everyone routine and the profane sphere.' See Weber, M. 2012, p. 361.

${ }^{48}$ This paragraph is developed and expanded upon in McGoey, L. and Thiel, D. in press, 2018. 'Charismatic Violence and the Sanctification of the Super-rich'. Economy and Society 42(1).

${ }^{49}$ McGoey and Thiel, ibid; see also Depecker, T., Déplaude, M.O., Larchet, N. 2018. 'La philanthropie comme investissement' Politix, dans ce dossier.
} 
incomprehensible personal sums given away, they are perceived as extraordinary acts of charity. ${ }^{50}$

Mega-donors like Gates and Zuckerberg thus come to symbolize a spirit of abnegation and self-sacrifice, personifying actions that many people revere most about life itself. After all, what 'normal' and profane person would give away most of their wealth to people they do not know? Rather than viewing the rhetorical inviolability surrounding large-scale philanthropy as primarily rooted in fear or a chilling effect, we thus argue that muted criticism is also attributable to the fact that philanthropic giving resides within the realm of the sacred - which grants it a form of perpetual immunity.

Such reverence for giving is, however, a view that ignores the financial, social and moral costs involved in the generation of the extraordinary personal wealth that allows it. This leads us back to our overarching question: why are people increasingly persuaded by the notion that the new philanthrocapitalists can 'save' the world when, at best, large-scale philanthropy has left global and national inequalities unaltered - and, at worst, has fomented increased inequality $?^{51}$ In the next section we draw on work from ignorance studies and critical criminology in order to highlight the continued non-acknowledgement of various forms of market-based costs and harms.

\section{Corporate costs and hidden harms}

There are many clear ways in which market liberalism and its supporting state systems have harmful effects. For example, it is widely known, if not actually acted upon, that the corporations which fuel individual super-wealth frequently contravene the law and are also repeat offenders. We have already mentioned the antitrust and union-busting activities of 'philanthropic' figures like Rockefeller and Carnegie in the $19^{\text {th }}$ century, and the antitrust case against Gates' Microsoft in the $20^{\text {th }}$ century - not to mention massive tax avoidance by companies such as Facebook that have generated extraordinary individual wealth accumulation. $^{52}$

\footnotetext{
${ }^{50}$ Nickel, P. 2015. "Haute Philanthropy: Luxury, Benevolence, and Value.” Luxury: History, Culture, Consumption 2 (2): 11-31.

${ }^{51}$ Hickel, J. ibid; Reich, R. 2006 "Philanthropy and Its Uneasy Relation to Equality," in William Damon and Susan Verducci, eds., Taking Philanthropy Seriously: Beyond Noble Intentions to Responsible Giving. Indiana University Press, Indianapolis. pp 27-50.

${ }^{52}$ Kravets, D. 2016. 'Facebook tells IRS it won't pay billions over Irish tax manoeuvre' Arstechnica, (October 12).
} 
In Edwin Sutherland's landmark book White Collar Crime (1949), he demonstrated how each of 70 corporations he analysed had, on average, 14 legal or regulatory decisions taken against them, the majority of which were made in a nine-year period from 1935-1944. Tellingly, these 70 companies were, 'with two exceptions, included in each of the 200 largest non-financial corporations in the United States'. ${ }^{53}$ Their offenses were, however, only very rarely dealt with by the police or criminal courts but, instead, by 'administrative commissions and of courts operating under civil or equity jurisdiction' ${ }^{54}$ The misdeeds of corporations were thus largely not included in criminal jurisdictions and this, Sutherland suggests, is part of the reason why corporations are only rarely seen as criminal and harmful.

Because corporate misdeeds mostly fall outside of criminal jurisdictions, this has farreaching implications in terms of how public perceptions of corporate wrongdoing are constructed. Corporations' relative immunity from criminal law and sanction essentially places a veil over the social and moral costs of business which are able to avoid the courts and criminal proceedings that act as proxy forms of collective public agreement, producing social truths about appropriate and inappropriate activity. ${ }^{55}$ The failure to identify and admonish corporate transgressions implies that those transgressions are not immoral, and it thereby places limits on public agreement about what is constructed as the truth of their behaviour. ${ }^{56}$

Since Sutherland's time, business has become even more immune to criminal sanctions and public criticism. In an increasingly global world whose fluid boundaries facilitate jurisdiction jumping, the proliferation of tax havens and a general lack of effective business regulation, ${ }^{57}$ comparable corporations and their associated wealth elites are even less likely to find themselves in contravention of regulations. Instead, they are better able to skirt them and, indeed, to bolster governmental action that produces regulations favourable to 'market principles'. ${ }^{58}$ Combined, these processes frame a pervasive moral silence pertaining to contemporary business harms and wrongdoing.

\footnotetext{
${ }^{53}$ Sutherland. ibid. p. 17.

${ }^{54}$ Ibid, p. 8.

${ }^{55}$ See Garland, D. 1991. Punishment and Modern Society. Clarendon Press, New York; Thiel, D., 2016. 'Moral Truth and Compounded Trauma: The Effects of Acquittal of Homicide Defendants on the Families of the Victims'. Homicide Studies 20 (3): 199-219.

${ }^{56}$ See Thiel, D. 2015.' Criminal Ignorance'. in M. Gross and L. McGoey (eds) Routledge International Handbook of Ignorance Studies. Routledge, London.

${ }^{57}$ Croal, H. 2005. Transnational White Collar Crime in J. Sheptyki and A. Wardak (eds) Transnational and Comparative Criminology. Glasshouse Press; Whyte, D. 2015. 'Introduction: A Very British Corruption', in D. Whyte (ed) How Corrupt is Britain? Pluto Press, London.

${ }^{58}$ Tombs, S. 2017 Social Protection After the Crisis: Regulation without Enforcement. Policy Press, Bristol.
} 
An entrenched perceptual and regulatory blindness has been erected over the wrongdoings of corporations and their financiers, and it has also become impossible for some to fail because public money regularly 'bails out' those it's governments' see as essential. While the former process effectively silences moral rebuke surrounding corporate wrong-doing - and, thereby empowers corporate wrongdoing, we argue, drawing on more recent work on 'crimes of the powerful', that a similar but more pervasive moral silence condenses around the social costs and harms generated by the increasingly powerful discursive and organisational separation of business from the state. This silence has both bolstered, and been bolstered by, dominant discourses about philanthrocapitalism.

One example is Tombs and Whyte's identification of otherwise hidden corporate harms. They point out that while the accounting sheets of corporations include the costs of materials, technology, energy, labour and premises, which are deducted from total sales to produce a picture of profit; these balance sheets 'externalise' the many social costs and harms of business on the life, death and health of workers, consumers, and the natural environment. These social costs - that are inevitably picked up by the public purse - are ignored by balancesheets and thus market logic, only very rarely prosecuted, and are indeed largely supported by states. The costs include those paid for by public taxation in terms of provision of police, regulators, social workers, and public health professionals for the numerous deaths, injuries, crisis and illness generated through poor working conditions, pollution, dangerous consumer products and housing, and large-scale environmental degradation. As Tombs and Whyte state:

It is the standard cost-accounting mechanisms used in standard accounting practice that reduce the value of death, injury, illness, widespread fraud, immiseration and environmental degradations to mere externalities; that is, peripheral side-effects of corporate activity, which remain absent from the balance sheets of costs and benefits of such activity... [In] almost every major case of corporate crime, corporations escape liability for the burden of the social costs: costs that always fall on the most vulnerable. ${ }^{59}$

As social costs are only rarely footed by business itself, they can be seen as kind of routinized 'tolerated criminality' ${ }^{60}$ that, as Edwin Sutherland's classic work illustrates, has roots stretching deep into history. Yet the powerful claims of the philanthrocapitalists and their

\footnotetext{
${ }^{59}$ Tombs, S. and Whyte, D. 2015. The Corporate Criminal: Why Corporations must be Abolished. Routledge, London. p. 15.

${ }^{60}$ Lea, J. ibid. p. 140 .
} 
supporters, including a number of governments, continue to hide and ignore the costs and criminality of the very business that they claim can save the world.

\section{The utility of strategic ignorance}

Consider the example of Bill Gates' championing of a 'self-interest'-based approach to global development work, and his use of Adam Smith's writings to defend his pro-market approach to global development. In 2008, at the height of the global financial crisis, Gates began to aggressively campaign for the introduction of a new paradigm: 'creative capitalism,' which he defines as 'an approach where governments, business, and nonprofits work together to stretch the reach of market forces so that more people can make a profit, or gain recognition, doing work that eases the world's inequities.' 61

This comment was made by Gates during a speech given at the World Economic Forum. Over subsequent years, he has lobbied vociferously for corporations such as Coca-Cola - where nearly one tenth of the Gates Foundation's endowment was invested until 2015 - to be seen as development 'partners' in meeting social goals like improved health, and thus worthy of government subsidies and philanthropic grants. The Gates Foundation's championing of CocaCola as a development 'partner' has been heavily criticised by public health experts, ${ }^{62}$ many of whom point out that Coca-Cola's aggressive marketing of unhealthy products undermines the Gates Foundation's global health goals. For example, over the past decade, Coca-Cola has quietly paid university researchers at Harvard University and elsewhere to carry out medical studies that sought to refute the known fact that excessive consumption of sugar can lead to obesity in children, deliberately fuelling public ignorance and confusion over the role that sugary drinks play in obesity. ${ }^{63}$

These strategies can be seen as a type of 'strategic ignorance,' a term which is defined as the effort to mobilize and exploit the unknowns and the uncertainties surrounding a corporate or government action in order to obtain greater political leverage, or reputational and financial

${ }^{61}$ Gates, B. 2008. 'Creative Capitalism' Speech, World Economic Forum, https://www.gatesfoundation.org/media-center/speeches/2008/01/bill-gates-2008-world-economicforum

62 D. Stuckler, S. Basu and M. McKee, 2011.'Global Health Philanthropy and Institutional Relationships: How Should Conflicts of Interest Be Addressed?' PLoS Med. 8(4) e1001020. doi:10.1371/journal.pmed.1001020

${ }^{63}$ O'Connon, A. 2015. 'Coca-Cola Funds Scientists Who Shift Blame for Obesity Away From Bad Diets'. New York Times. (August 19). 
rewards. ${ }^{64}$ Strategic ignorance takes many forms, including the cherry-picking of selective evidence to support a prior policy position while obscuring evidence of the ways the same policy is flawed or even harmful. To date, most scholarship on strategic ignorance has focused on corporate and state actors, and comparatively less attention has been paid to the ways that think-tanks and civil society organizations, including philanthropic organizations and celebrity figureheads such as Gates, also draw selectively on self-serving evidence. ${ }^{65}$

In this section, we seek to narrow that gap by highlighting two ways in which Gates's powerful ideology of market munificence can be seen as a form of strategic ignorance. The first is his assumption that marrying social profits with social welfare will lead to frictionless gains for all. The second is his reliance on a narrow understanding of Adam Smith's writing to defend his notion of 'creative capitalism.' For example, as Gates stated in a speech to the World Economic Forum in 2008:

Adam Smith... believed strongly in the value of self-interest for society... creative capitalism takes this interest in the fortunes of others and ties it to our own interests in our own fortunes - in ways that help advance both.

This is a narrow and misguided interpretation of Smith's writing. As scholars such as Harcourt and Sutherland point out, Smith's published work and private letters make very clear his strong opposition to unfettered corporate activity and corporate monopoly practices. In short, Smith worried that collusion among business merchants enabled them to connive and 'conspire' against the public, and he thus saw a strong role for the state in policing harmful corporate practices. $^{66}$

Although Gates' statement might appear at first glance to be an innocuous and even a commendable way to increase corporate responsibility to the public, he is actually calling something far more unusual. By suggesting that companies should be entitled to earn a profit

\footnotetext{
${ }^{64}$ See McGoey, L. 2012. 'The Logic of Strategic Ignorance.' British Journal of Sociology; Rayner, S. 2012. 'Uncomfortable knowledge'. Economy and Society, 41:1, 107-125; Girel, M. 2017. Science et territoires de l'ignorance. Quae, Paris; Gross, M. 2010. Ignorance and Surprise: Science, Society and Ecological Design. MIT Press; Freidberg, S. 2018. 'Trading in the Secretive Commodity' Economy and Society. 46(3-4): 499-521 ; Henry (E.), Ignorance scientifique et inaction publique. Les politiques de santé au travail, Paris, Presses de Sciences Po, 2017; Jas (N.), "Ignorance dans le 'gouvernement' des substances chimiques dangereuses", Raison Présente, 204, 2017; Déplaude (M.-O.), "Les infortunes de la vertu. Sociologie d'un répertoire d'action patronal", Sociologie du travail, 56(4), 2014; Fillion (E.), Torny (D.), "Un précédent manqué : le Distilbène ${ }^{\circledR}$ et les perturbateurs endocriniens. Contribution à une sociologie de l'ignorance." Sciences sociales et santé, 34(3), 2016. ${ }^{65}$ One notable exception is Slater, T. 2014. 'The myth of 'Broken Britain': welfare reform and the production of ignorance.' Antipode 46(4): 948-969.

${ }^{66}$ Harcourt, B. 2011. The Illusion of Free Market' Harvard University Press; Sutherland, K. 1993. 'Introduction,' in Smith, A. Wealth of Nations, (ed) Sutherland, K, Oxford University Press.
} 
from 'doing work that eases the world's inequities,' Gates is calling for financial reimbursement of corporations for their 'social' efforts in a manner that even the most staunch, pro-market ideologues in the past would not dare to suggest.

Even the right-wing economist Milton Friedman, for example, was wary that businesses should assume a 'social mission,' because he presumed that doing so would force corporations to open themselves up to greater democratic oversight. Friedman was sceptical of any entity, either governmental or private, which 'affected to trade for the public good,' a quotation from Adam Smith's Wealth of Nations that Friedman references in his influential 1970 essay, 'The Social Responsibility of Business is to Increase its Profits' ${ }^{67}$ Friedman's biggest concern was that if the corporation was tasked with fulfilling social needs, then any such expansion of the remit of the corporation would require more public oversight over how corporations are run. ${ }^{68}$

Today's philanthrocapitalists explicitly refute Friedman's insistence that the sole aim of a corporation should be to maximize shareholder profits. Presenting their mission as a more humane and conscientious approach, they claim to have pioneered a 'softer' and more 'creative' form of capitalism wherein corporations voluntarily 'partner' with governments in order advance general social welfare. Yet, importantly, today's philanthrocapitalists also argue that businesses need to be properly incentivized to do so. In many ways, therefore, the new philanthrocapitalist rhetoric advances an even more extreme notion of market superiority than Friedman did because, unlike him, they make an explicit normative case for using public money to subsidize the corporate sector's 'social work.'

The emergence of today's philanthrocapitalism movement thus represents an important ideological shift whereby its supporters have managed to build a normative case for enlisting the private sector in public services delivery. Charismatic love and strategic ignorance have combined to sanctify and normalise 'the market' as both separate and superior to public institutions - to the point where even known problems surrounding the wastefulness and harmful effects of outsourcing social and public services to for-profit stakeholders becomes taboo, as our final section shows.

\section{Harmony ideology and corporate 'partners'}

\footnotetext{
${ }^{67}$ Friedman, M. 1970. 'The Social Responsibility of Business is to Increase its Profits'. New York Times Magazine, (Sept. 13); see also Smith, A. (1972) Wealth of Nations, Oxford World Classics, p. 292.

${ }^{68}$ For further discussion on Friedman's influence on notions of corporate responsibility, see Djelic, ML, and Ectchanchu, H. 2017. 'Contextualizing Corporate Political Responsibilities: Neoliberal CSR in Historical Perspective'. Journal of Business Ethics 142: 641-661.
} 
There have been major shifts in public services delivery in developed neoliberal political economies like the United Kingdom and United States, as well as in numerous developing countries where International Financial Organisations including the World Bank and the International Monetary Fund dictate market-based reforms of public services - often with deleterious consequences. ${ }^{69}$

The UK was one of the first developed countries to develop a neo-private contracting model, known as the Private Finance Initiative (PFI), an apparently new type of financial investment and procurement instrument that became dominant over the past 30 years. In the US, PFIs are commonly called 'public-private partnerships'; in France, they are 'contrat de partenariat' (CP), and were first implemented there in 2004 following the introduction of new legislation - partly inspired by the apparent cost-effectiveness of the UK PFI model. Despite their different names, all refer to a similar model of financing whereby the provision of a public good or service is tendered to a competitive bidding process, with the winning organization then awarded regular, guaranteed government payments in exchange for delivering a service. The services include the building and the management of public buildings like schools, hospitals, prisons and social housing, as well as the management, administration, catering, cleaning and maintenance of public services.

The use of private contractors to deliver public services was championed on a basis of a 'value-for-money' argument, predicated on the idea - the same idea championed by philanthrocapitalists - that the private sector is inherently more efficient than the public sector. There is however growing evidence that PFIs have been grossly wasteful, leading to fierce and cross-partisan criticism about their use in the UK. ${ }^{70}$ Additionally, the executives of many PFIproviding companies have garnered huge salaries and bonuses, including those representing companies that have failed and filed for bankruptcy ${ }^{71}$ - the debts of which are inevitably footed by the public.

\footnotetext{
${ }^{69}$ See, for example, Friderichs, D. and Friederichs, J. 2002. 'The World Bank and Crimes of Globalisation: A Case Study', Social Justice 29: 1-12; Rothe, D., Mullins, C., and Sandstrom, K. 2008. 'The Rwandan Genocide: International Financial Policies and Human Rights', Social Justice 35(3): 6686.

${ }^{70}$ Curry, R. 2018. 'Little evidence that PFI contracts are good value, NAO report finds.'The Telegraph, (January 18). See also Standing, G. 2016. The Corruption of Capitalism: Why Rentiers Thrive and Work Doesn't Pay. Biteback Publishing, London; Mair, M. and Jones, P. 2015. 'Politics, Government and Corruption: The Case of the Private Finance Initiative', in D. Whyte (ed) How Corrupt is Britain? Pluto Press, London. p. 127.

${ }^{71}$ See Hildyard, L. (2017) High Pay and Corruption, in D. Whyte (ed) How Corrupt is Britain? London: Pluto; and Hodkinson, S. 2011. 'Housing Regeneration and the Private Finance Initiative in England: Unstitching the Neoliberal Urban Straitjacket'. Antipode 43(2): 358-383.
} 
The use of PFIs is believed to be playing a role in exacerbating unemployment, limiting access to social housing, and increasing inequality in regions where it has been introduced. ${ }^{72}$ Yet government failure to effectively regulate the corporate misbehaviour and funding mismanagement involved in many PFIs stifles public condemnation. It is only when significant individual scandals, such as the recent collapse of the service provider, Carillion, in the UK, attract bursts of scrutiny to the model of public funding that has underpinned the huge expansion of companies like Carillion and other state-funded public sector contracting organizations. $^{73}$

The explosive growth of PFIs used today in the UK is unprecedented - but the 'partnership' model they represent has a long heritage. Just as today's philanthrocapitalists argue that charity is better if administered by market-oriented mechanisms, they also frequently suggest there is something radical and unprecedented about state-corporate partnerships to deliver public services. This is not the case: the state and the market have, of course, long been intertwined, with hybrid state-business models used to deliver social services throughout the $19^{\text {th }}$ and $20^{\text {th }}$ centuries. For example, with the development of the modern British state in the 19th century, the construction of its many public buildings and infrastructure was carried out almost entirely by private building contractors. Yet, by the close of that century, due to growing evidence and concerns about corrupt bidding practices and poor-quality construction, local government began to directly organise and supply the labour for the construction of their public works - a situation that dominated UK public building until the early $1980 \mathrm{~s}^{74}$

Public-private collaborations through modern industrial history had, at best, mixed results, with the ineffective regulation of interests often leading to significant costs and harm to the public - a problem, as we outlined above, that Adam Smith warned about. Today, there is growing concern from development specialists and public health scholars who suggest that the skyrocketing growth of the private 'financing' of public services is far costlier to taxpayers than earlier models of government procurement. ${ }^{75}$ Despite this, influential proponents of

\footnotetext{
${ }^{72}$ Pensiero, N. 2017. 'In-house or outsourced public services? A social and economic analysis of the impact of spending policy on the private wage share in OECD countries' International Journal of Comparative Sociology 2017: 58(4) 333-351.

${ }^{73}$ Singh, A. 2018 'After Carillion, social enterprises must take charge of public services' The Guardian, $18^{\mathrm{h}}$ January. https://www.theguardian.com/voluntary-sector-network/2018/jan/18/carillion-collapsepublic-services-social-enterprise-preferred-partner. Last accessed 27/02/18.

${ }^{74}$ Langford, D. 1982. Direct Labour Organisations in the Construction Industry. Gower, Aldershot; Thiel, D. 2012. Builders: Class, Gender and Ethnicity in the Construction Industry. Routledge, London. ${ }^{75}$ Development economist Maria Romero has noted that public-private partnerships 'are usually the most expensive method of delivering development projects.' Romero, M.J. 2015. 'International private finance for development: Risky business?' Insights Magazine. 4(5). August/September.
} 
market solutions, including many philanthrocapitalists, continue to vociferously promote 'forprofit' mechanisms for public service delivery, especially when it comes to education and global health. ${ }^{76}$

Partnerships between the private sector and state actors are thus not themselves new, but rather they are a reintroduction of a model of government-corporate service delivery that dominated the UK before the mid- $20^{\text {th }}$ century construction of the welfare state. But this long history is, in itself, a salient fact that speaks to a curious but unanswered question: why is the corporate mismanagement of public service projects not more widely acknowledged today by the general public? We suggest that the misrecognition of corporate harms stems, firstly, from the authoritative magic, generated by mega-giving, that is dressed upon market principles; secondly, by 'externalization' of social costs from the business of profit, and; thirdly, by associated strategic ignorance of corporate parasitism on state support and the role this plays in compounding inequality.

The combined effects of these features can be understood in terms of what Jürgen Habermas called the systemic colonisation of the 'lifeworld', whereby a new faction in society - in this case, advocates of philanthrocapitalism - attempts to 'make good' in relation to social welfare programmes - yet selectively excludes certain themes and contributions from public discussion, neutralising the possibilities for public participation in decision-making. ${ }^{77}$ Here, the historically constructed 'naturalness' of market logic serves to de-differentiate the political 'sub-system' of state and entrepreneurial endeavours in relation to welfare provision, while simultaneously propelling the 'symbolic self-presentation' of neoliberal elites to the forefront of the public sphere. ${ }^{78}$

Under such circumstances, philanthrocapitalism serves as a powerful 'defensive shield for the vagaries of capitalism' - especially as the colonised political and ethical ground obscures the potential for deeper scrutiny of market operations while, at the same time, accountability becomes increasingly diffused. ${ }^{79}$ As Colin Crouch observes, such powerful

http://ecdpm.org/great-insights/private-sector-matters/international-private-finance-developmentrisky-business/.

${ }^{76}$ Romero, ibid.

${ }^{77}$ Habermas, J. 1987. The Theory of Communicative Action: Critique of Functionalist Reason v. 2. Polity, Cambridge. p. 375.

${ }^{78}$ Ibid, p. 346.

${ }^{79}$ Rodger, J. 2013. "NNew capitalism”, colonisation and the neo-philanthropic turn in social policy: Applying Luhmann's Systems Theory to the Big Society Project' International Journal of Sociology and Social Policy, 33 (11/12): 725-741.. See also Hodge, G. and Greve, C. 2010. 'Public-Private Partnerships: Governance Scheme or Language Game?'. The Australian Journal of Public Administration, 69 (1):8-22. 
elites gain leverage over political systems by 'polluting' the channels of more traditional conduits through which substantive public concerns and actions are directed in liberal democracies $^{80}$. This, we argue, has self-fulfilling propensity that limits the public's 'flows of concerns' to those raised by powerful actors - and it thus comes to normalize the social costs and harms of the market model and to hide market dependence on the state, paving the way for colonisation of the public realm by market logic.

\section{Conclusion: Gifts and Smiles}

Sometimes new social practices solidify as tolerable and even admirable so quickly that people forget that, not long before, those same practices were seen as unacceptable or even harmful and the philanthrocapitalism movement provides one such example. ${ }^{81}$ Until recently, the idea that personal profiteering is naturally 'philanthropic' for the wider community and inevitably beneficial to humankind was a laughable proposition. Today this has changed, and the concept of philanthrocapitalism is being hailed across the political spectrum as a laudable way to improve human welfare, and, in just over 10 years, the notion of philanthrocapitalism has evolved from a derided fridge philosophy to a powerful 'gospel' of wealth.

We have examined the origins of this new movement and suggested reasons for its growing dominance. The charismatic authority and ensuing 'perpetual immunity' granted to such organizations helps to illustrate how and why institutions like the Gates Foundation have managed to successfully rebrand private financial returns as naturally munificent, despite the lack of empirical evidence to support the claim that new 'profit-incentivising' models of philanthropy and public services delivery are effective at narrowing economic inequalities or reducing global poverty. ${ }^{82} \mathrm{We}$ have also suggested that strategic ignorance of the long history of costly public-private partnerships is associated with widespread regulatory and social blindness towards corporate harms. This has opened the way for public's enrichment of private actors who deliver public services on a for-profit basis to become taken for granted. Thus, even as we see the social harms of under-regulated private profiteering before our eyes, our focus is obscured by powerful sermons that ignore or neglect inconvenient evidence. Philanthrocapitalist pronouncements about the value of combining social welfare with business

\footnotetext{
${ }^{80}$ Crouch, C. 2011. The Strange Non-Death of Neo-Liberalism.: Polity, Cambridge.

${ }^{81}$ Cassidy, J. 2015. 'Mark Zuckerberg and the Rise of Philanthrocapitalism'. The New Yorker, (December 3).

${ }^{82}$ Hickel, ibid.
} 
profitability has become part of our 'natural attitude' - and, as Schutz long ago observed, what we take for granted we tend not to see. ${ }^{83}$

In aligning our critique of philanthrocapitalism with literature addressing "crimes of the powerful,' we have shown how the social costs of extreme capital accumulation are obscured by the sanctification of philanthropic giving. Here, sanctification acts as both 'sanctuary and disguise 84 that mystifies the reality of social harms engendered through unregulated market practices. Through this process, the business of capital accumulation falsely appears as uncoupled from the state support and public money that it is dependent on - and a disingenuous impression is created that market practices are more cost-effective than they really are.

Indeed, in light of a long history of under-policed and under-punished corporate criminality, the philanthropy of elite donors is, at its best, simply paying back part of the social and economic costs that have been generated by their business and personal super-wealth. Yet, with the emergence of profitable private-public partnerships and the new practice of offering direct philanthropic gifts to large corporations, organizations like the Gates Foundation enable companies like Mastercard to present their own wealth-maximizing strategies as a form of 'giving back' - making it appear as if they are selflessly pursuing the public good. In doing so, rather than alleviating the costliness of public service provision, marketized charity and public services actually amplify the social harms generated by market-driven capitalism.

The novelty of our approach has been to document the role that philanthrocapitalists play in proselytizing a gospel of market munificence. We have shown that what is really new about the 'new' philanthropy is not the comparative magnitude of new giving practices, but the structure of giving, and particularly the worrying and likely harmful enlargement of the sphere of entities, public or private, that are deemed as deserving charity. These structural changes have enabled organizations such as the Gates Foundation to use comparatively small 'gifts' in order to command widespread public allegiance and even reverence - smothering demands for corporate accountability and higher taxes. Old metaphors about the 'vampire-like' tendencies of capitalists have missed the most important thing to remember about vampires: they are most dangerous when circulating in disguise among the living, offering a warm smile that conceals their darker being.

\footnotetext{
${ }^{83}$ Schutz, A. 1967. The Phenomenology of the Social World. Northwestern University Press, Illinois.

${ }^{84}$ Lea, J. 2002. Crime and Modernity. Sage, London. p. 151.
} 